\title{
PENGARUH FAKTOR MAKRO EKONOMI TERHADAP PERGERAKAN INDEKS HARGA SAHAM GABUNGAN (IHSG) DI BURSA EFEK INDONESIA PERIODE 2017-2020
}

\author{
ESLI SILALAHI ${ }^{1}$ \\ RIDO SIHOMBING \\ Fakultas Ekonomi Universitas Katolik Santo Thomas \\ $\underline{\text { esli2silalahi@gmail.com }}{ }^{1}, \underline{\text { rshbing@gmail.com }}{ }^{2}$
}

\begin{abstract}
ABSTRAK
Penelitian ini bertujuan untuk mengetahui pengaruh faktor makro ekonomi, yaitu : Kurs, Inflasi, Suku Bunga BI dan Pertumbuhan Ekonomi terhadap Indeks Harga Saham Gabungan (IHSG) di Bursa Efek Indonesia (BEI) periode 2017-2020 Metode pengumpulan data yang digunakan adalah tehnik dokumentasi dengan memperoleh data yang dapat diakses melalui www.bi.go.id, www.idx.co.id, www.bps.go.id, penelusuran dokumen, atau publikasi informasi. Populasi penelitian semua periode perdagangan tahun 2017-2020 di Bursa Efek Indonesia, dengan teknik pengambilan sampel menggunakan Non-Random Sampling yaitu dengan metode Purposive sampling dengan pertimbangan bahwa selama periode pengamatan, Bursa Efek Indonesia (BEI) telah mengalami market bearish dan market bullish karena dipengaruhi oleh berbagai makro ekonomi sehingga sesuai dengan tujuan penelitian. Metode analisis yang digunakan adalah analisis regresi linear berganda, dengan melakukan uji asumsi klasik yaitu: uji normalitas, uji multikolonieritas dan uji heteroskedastisitas, dan uji autokorelasi kemudian melakukan pengujian hipotesis yaitu uji t dan uji F untuk menguji secara empiris pengaruh faktor makro-ekonomi, yaitu : Kurs, Inflasi, Suku Bunga BI dan Pertumbuhan Ekonomi terhadap Indeks Harga Saham Gabungan (IHSG) di Bursa Efek Indonesia (BEI) periode 2017-2020. Hasil uji secara Parsial (uji t) menunjukkan bahwa Kurs berpengaruh negatif dan signifikan terhadap indeks harga saham gabungan, Inflasi berpengaruh negatif dan signifikan terhadap indeks harga saham gabungan, Suku bunga BI berpengaruh positif dan signifikan terhadap indeks harga saham gabungan dan Pertumbuhan ekonomi berpengaruh positif dan signifikan terhadap indeks harga saham gabungan. Hasil uji secara simultan (uji F) menunjukkan bahwa Kurs, Inflasi, Suku Bunga Bank Indonesia (SBI) dan Pertumbuhan Ekonomi (GDP) berpengaruh signifikan terhadap indeks harga saham gabungan di Bursa Efek Indonesia.
\end{abstract}

Kata kunci : Kurs, Inflasi, Suku Bunga BI, Pertumbuhan Ekonomi, Indeks Harga Saham Gabungan.

\section{PENDAHULUAN}

Pasar modal adalah salah satu alat penggerak perekonomian di suatu negara, karena pasar modal merupakan sarana pembentuk modal dan akumulasi dana jangka panjang yang diarahkan untuk meningkatkan partisipasi masyarakat dalam penggerakan dana guna menunjang pembiayaan pembangunan nasional. Pasar modal juga merupakan sarana perusahaan untuk meningkatkan kebutuhan dana jangka panjang dengan menjual sahamnya atau mengeluarkan obligasi. Pasar modal bertujuan untuk memfasilitasi perdagangan atas klaim terhadap bisnis perusahaan, sehingga pasar modal dapat memberikan dampak yang signifikan terhadap investasi (Rivai, 2009).

Selain itu, pasar modal juga merupakan representasi untuk menilai kondisi perusahaan di suatu negara, karena hampir semua industri di suatu negara terwakili oleh pasar modal. Pasar modal yang mengalami peningkatan (bullish) atau mengalami penurunan (bearish) terlihat dari naik turunnya harga harga saham yang tercatat yang tercermin melalui suatu pergerakan Indeks Harga Saham Gabungan (IHSG). 
Indeks harga saham gabungan (IHSG) sebagai salah satu barometer kesehatan ekonomi negara dan dapat menjadi salah satu landasan analisis statistik atas kondisi pasar saat ini. Jika terjadi kenaikan pada IHSG berarti ada perbaikan kinerja perekonomian negara. Namun sebaliknya, jika terjadi penurunan pada IHSG berarti adanya indikasi permasalahan pada perekonomian negara. Pergerakan IHSG dipengaruhi oleh beberapa faktor, salah satunya berasal dari makro ekonomi. Faktor Makro Ekonomi meliputi kurs (Nilai tukar) di suatu negara terhadap negara lain, Inflasi, Tingkat suku bunga BI dan Pertumbuhan Ekonomi yang terjadi di negara tersebut

Salah satu faktor yang dapat mempengaruhi pergerakan indeks harga saham gabungan adalah kurs atau nilai tukar. Nilai kurs mata uang berkaitan dengan keuntungan perusahaan yang menggunakan bahan baku impor. Jika kurs melemah atau mengalami depresiasi keuntungan perusahaan akan turun akibat naiknya biaya bahan baku impor. Jika keuntungan menurun harga saham perusahaan kemugkinan mengalami penurunan dan berakibat pada menurunnya IHSG. Untuk menjaga stabilitas nilai tukar, bank sentral pada waktu-waktu tertentu melakukan intervensi di pasar-pasar valuta asing, khususnya pada saat terjadi gejolak yang berlebihan (Situmorang 2008). Handiani (2014) menyatakan bahwa kurs rupiah berpengaruh positif terhadap IHSG, berbeda dengan penelitian Yusnita Jayanti (2012) menyatakan bahwa kurs rupiah terhadap dolar berpengaruh negatif terhadap IHSG.

Faktor Makro Ekonomi selanjutnya yang mempengaruhi IHSG yaitu inflasi. Inflasi adalah kecenderungan terjadinya peningkatan harga produk-produk secara keseluruhan sehingga terjadi penurunan daya beli uang, Tandelilin (2010), Inflasi yang berlebih selalu berdampak buruk bagi perekonomian. Dampak inflasi dapat menimbulkan akibat buruk kepada individu, masyarakat dan kegiatan perekonomian secara keseluruhan (Sukirno 2006). Dampak ini juga dapat menimbulkan barang- barang menjadi langka di pasaran karena para konsumen cemas dengan kenaikan harga barang di keesokan harinya sehingga mereka terkena sindrom hoarding of goods (menimbun barang-barang/penimbunan) karena mereka lebih tenang menyimpan barang-barang kebutuhan daripada uang.

Diantoro (2010).Thobarry (2009) juga menyatakan bahwa inflasi berpengaruh signifikan terhadap IHSG. Akan tetapi kontradiksi dengan hasil penelitian Wibowo et.al (2016) yang menyatakan bahwa inflasi tidak berpengaruh terhadap IHSG.

Faktor Makro Ekonomi lain yang mempengaruhi IHSG adalah suku bunga Bank Indonesia (SBI). SBI adalah surat berharga dalam mata uang rupiah yang diterbitkan oleh Bank Indonesia sebagai pengakuan utang berjangka waktu pendek dengan sistem diskonto. Kenaikan tingkat suku bunga SBI akan diikuti oleh bank-bank komersial untuk menaikkan tingkat suku bunga simpanan.

Tingkat bunga dan harga saham mempunyai relasi yang negatif (Kewal, 2012). Tingkat bunga yang sangat tinggi dapat memberikan pengaruh nilai masa kini (present value) aliran kas perusahaan, sehingga peluang investasi yang ada tidak akan menarik lagi. Tingkat bunga yang sangat tinggi juga dapat meningkatkan biaya modal dimana akan ditanggung perusahaan sehingga menyebabkan return yang diisyaratkan pemberi modal dari suatu investasi akan meningkat. Beberapa hasil penelitian menyatakan bahwa suku bunga BI berpengaruh negatif terhadap IHSG, Kumalasari et.al (2016) tetapi kontradiksi dengan penelitian Indra Maimuna (2017) menyatakan bahwa suku bunga SBI tidak berpengaruh signifikan terhadap IHSG.Dan faktor Makro Ekonomi yang terakhir yang digunakan dalam penelitian ini adalah Pertumbuhan Ekonomi. Pertumbuhan Ekonomi adalah jumlah produksi barang dan jasa yang dihasilkan oleh unit-unit produksi pada suatu daerah di saat-saat tertentu, Pertumbuhan Ekonomi dapat dilihat dari hasil Produk domestic Bruto (PDB). PDB yang tumbuh cepat menunjukkan pertumbuhan ekonomi yang berdampak pada meningkatnya daya beli masyarakat. PDB atas dasar harga berlaku menggambarkan nilai tambah barang dan jasa yang dihitung menggunakan harga yang berlaku pada setiap 
tahun, sedangkan Produk Domestik Bruto (PDB) atas harga konstan digunakan untuk mengetahui pertumbuhan ekonomi dari tahun ke tahun. Dari beberapa hasil penelitian yang diuraikan diatas masih terdapat inkonsisten hasil maka dilakukan replikasi penelitian Pengaruh Kurs, Inflasi, Suku Bunga BI dan Pertumbuhan Ekonomi terhadap Pergerakan Indeks Harga Saham Gabungan di Bursa Efek Indonesia Periode 2017-2020

\section{TINJAUAN PUSTAKA DAN HIPOTESIS}

\section{Theory Signalling}

Teori Sinyal menjelaskan tentang bagaimana para investor memiliki informasi yang sama tentang prospek perusahaan. Teori signaling dikembangkan dalam ilmu ekonomi dan keuangan untuk memperhitungkan kenyataan bahwa orang dalam (insiders) perusahaan pada umumnya memiliki informasi yang lebih baik dan lebih cepat berkaitan dengan kondisi mutakhir dan prospek perusahaan dibandingkan dengan investor luar. Teori ini menjelaskan bahwa laporan keuangan yang baik merupakan sinyal atau tanda bahwa perusahaan juga telah beroperasi dengan baik..Informasi yang dipublikasikan sebagai suatu pengumuman akan memberikan signal bagi investor dalam pengambilan keputusan investasi. Jika pengumuman tersebut mengandung nilai positif, maka pasar akan bereaksi baik dengan pihak lain. Reaksi pasar ditunjukkan dengan adanya perubahan volume perdagangan saham. Pada waktu informasi diumumkan dan semua pelaku pasar sudah menerima informasi tersebut, pelaku pasar terlebih dahulu menginterpretasikan dan menganalisis informasi tersebut sebagai signal baik bagi investor, maka terjadi perubahan dalam volume perdagangan saham.

Fahmi (2015) signalling theory adalah teori yang membahas tentang naik turunya harga saham di pasar, sehingga akan memberi pengaruh terhadap keputusan investor. signaling theory merupakan suatu perilaku manajemen perusahaan dalam memberi petunjuk untuk investor terkait pandangan manajemen pada prospek perusahaan untuk masa mendatang, Brigham dan Houston (2014).Teori Sinyal juga mengemukakan tentang bagaimana seharusnya sebuah perusahaan memberikan sinyal kepada pengguna laporan keuangan. Teori sinyal menekan bahwa informasi yang di umumkan kepada publik baik yang bersifat negatif maupun positif akan memberikan pengaruh terhadap keputusan investor dalam berinvestasi, mereka akan bereaksi dengan berbagai cara dalam menanggapi sinyal tersebut. Jogiyanto (2017)

\section{Faktor Makro Ekonomi yang mempengaruhi IHSG}

Kurs adalah salah satu harga terpenting bagi suatu negara yang sistem perekonomiannya terbuka karena mengingat pengaruhnya besar dalam berbagai transaksi internasional. Kurs merupakan alat pengukuran yang digunakan untuk menilai harga mata uang domestik terhadap mata uang negara lain. Nilai tukar adalah nilai atau harga mata uang suatu negara yang dinilai dengan mata uang negara lainnya. Nilai kurs (Rp/US\$) adalah harga satu unit dollar (US\$) yang ditunjukkan dalam mata uang rupiah. Kenaikan nilai tukar mata uang dalam negeri disebut apresiasi atas mata uang asing. Penurunan nilai tukar uang dalam negeri disebut depresiasi atas mata uang asing.

Kurs atau nilai tukar adalah suatu nilai yang menunjukkan jumlah nilai mata uang dalam negeri yang diperlukan untuk mendapatkan satu unit mata uang asing (Sukirno 2006). Nilai tukar yang melonjak secara drastis tak terkendalikan akan menyebabkan kesulitan pada dunia usaha dalam merencanakan usahanya terutama bagi mereka yang mendatangkan bahan baku dari luar negeri atau menjual barangnya ke pasar ekspor. Oleh karena itu, pengelolaan nilai mata uang yang relatif stabil menjadi salah satu faktor moneter yang mendukung perekonomian secara makro. Pohan (2008).

Kurs rupiah yang melemah terhadap dolar AS juga ikut mempengaruhi IHSG. Selain para investor dapat berinvestasi di pasar modal, mereka juga dapat berinvestasi di pasar valas. 
Melemahnya nilai rupiah terhadap dolar AS akan menarik minat investor untuk berinvestasi di pasar valas. Selain itu, melemahnya kurs rupiah akan berdampak pada menurunnya laba bersih yang diperoleh oleh emiten sehingga mengakibatkan harga sahamnya juga ikut menurun. Pelemahan kurs rupiah terhadap dolar AS akan memicu terjadinya inflasi di masyarakat.

Inflasi merupakan suatu kejadian yang menggambarkan situasi dan kondisi dimana harga barang mengalami kenaikan dan nilai mata uang mengalami pelemahan. Jika kondisi ini terjadi secara terus-menerus, akan berdampak pada semakin buruknya kondisi ekonomi secara menyeluruh serta terjadi guncangan pada tatanan stabilitas politik suatu negara (Fahmi, 2015).

Secara sederhana inflasi diartikan sebagai meningkatnya harga-harga secara umum dan terus menerus. Kenaikan harga dari satu atau dua barang saja tidak dapat disebut inflasi kecuali bila kenaikan itu meluas (atau mengakibatkan kenaikan harga) pada barang lainnya. Indikator yang sering digunakan untuk mengukur tingkat inflasi adalah Indeks Harga Konsumen (IHK). Perubahan IHK dari waktu ke waktu menunjukkan pergerakan harga dari paket barang dan jasa yang dikonsumsi masyarakat.

Menurut Raharjo (2012), suku bunga BI rate adalah suku bunga untuk menanggapi perubahan inflasi dan nilai tukar rupiah sebagai acuan untuk suku bunga perbankan seperti suku bunga tabungan dan deposito. Bank Sentral atau Bank Indonesia memiliki otoritas dalam mengubah suku bunga secara umum.

Biasanya Bank Indonesia akan mengubah suku bunga BI rate atau SBI (Sertifikat Bank Indonesia) untuk menanggapi perubahan inflasi. Jika inflasi tinggi atau nilai tukar rupiah merosot, biasanya Bank Indonesia akan menaikkan BI rate dan SBI. Penerbitan SBI dilakukan atas unjuk dengan nominal tertentu dan penerbitan SBI biasanya dikaitkan dengan kebijakan pemerintah terhadap operasi pasar terbuka (open market operation) dalam masalah penanggulangan jumlah uang beredar. Tekanan kuat yang mengharuskan pemerintah menaikkan suku bunga berkaitan dengan melonjaknya inflasi dan semakin terpuruknya kurs rupiah terhadap dollar Amerika.

BI rate yang telah ditetapkan oleh Bank Indonesia dapat dijadikan sebagai suku bunga acuan oleh bank-bank yang ada di Indonesia dalam menentukan besarnya suku bunga simpanan dan pinjaman serta digunakan oleh Bank Indonesia sebagai sasaran suku bunga SBI yang diinginkan untuk pelelangan pada masa periode tertentu. Tinggi rendahnya BI rate ini akan mempengaruhi investasi di pasar modal karena investor dapat mengalihkan dana investasinya dalam bentuk simpanan di bank lokal dan pembelian SBI di pasar uang sehingga berdampak pada merosotnya IHSG di Bursa Efek Indonesia (BEI).

Pertumbuhan ekonomi merupakan masalah perekonomian suatu negara dalam jangka panjang menuju keadaan yang lebih baik selama periode tertentu dan dapat dikaitkan juga sebagai keadaan kenaikan kapasitas produksi suatu perekonomian yang diwujudkan dalam bentuk kenaikan pendapatan nasional. Adanya pertumbuhan ekonomi merupakan indikasi keberhasilan pembangunan ekonomi. Dalam analisis makro pertumbuhan ekonomi yang dicapai oleh satu negara diukur dari perimbangan pendapatan nasional rill yang dicapai satu negara.

Pertumbuhan ekonomi merupakan sebuah mekanisme kenaikan output perkapita dalam kondisi jangka panjang (Boediono, 1999). Pengertian tersebut mencakup 3 aspek, yaitu :mekanisme, output perkapita serta jangka panjang. Pertumbuhan ekonomi disebut juga sebagai suatu mekanisme, dan bukan gambaran ekonomi pada suatu saat. Aspek yang dinamis dicerminkan dari suatu perekonomian, sehingga kita dapat melihat bagaimana suatu perekonomian dapat berkembang atau dapat berubah dari kurun waktu ke waktu. Pertumbuhan ekonomi dikaitan dengan mekanisme kenaikan output perkapita. Dalam hal ini terkait dengan output total serta jumlah penduduk, karena output perkapita merupakan output total yang dibagi dengan jumlah penduduk. Sehingga mekanisme kenaikan output perkapita 
wajib dianalisa dengan melihat apa yang telah terjadi dengan ouput total disatu sisi, dan jumlah penduduk di sisi yang lain nya. Dengan perkataan lain, bahwa pertumbuhan ekonomi kajiannya mencakup pertumbuhan GDP dan pertumbuhan penduduk.

Indeks harga saham gabungan (IHSG) mengukur nilai kinerja seluruh saham yang tercatat di suatu bursa efek dengan menggunakan semua saham yang tercatat di bursa efek sebagai komponen penghitungan indeks. IHSG digunakan untuk mengetahui perkembangan dan situasi umum pasar modal, bukan situasi perusahaan tertentu. Indeks ini mencakup pergerakan harga seluruh saham biasa dan saham preferen yang tercatat di BEI.

Menurut Anoraga dan Pakarti (2008) IHSG merupakan indeks yang menunjukkan pergerakan harga saham secara umum yang tercatat di bursa efek yang menjadi acuan tentang perkembangan kegiatan di pasar modal. IHSG ini bisa digunakan untuk menilai situasi pasar secara umum atau mengukur apakah harga saham mengalami kenaikan atau penurunan. IHSG juga melibatkan seluruh harga saham yang tercatat di bursa.

IHSG dapat menggambarkan keadaan pasar yang wajar, Bursa Efek Indonesia berwenang mengeluarkan atau tidak memasukkan satu atau beberapa Perusahaan Tercatat dari perhitungan IHSG. Dasar pertimbangannya antara lain, jika jumlah saham Perusahaan Tercatat tersebut yang dimiliki oleh publik (free float) relatif kecil sementara kapitalisasi pasarnya cukup besar, sehingga perubahan harga saham Perusahaan Tercatat tersebut berpotensi mempengaruhi kewajaran pergerakan IHSG.

\section{Pengaruh Kurs (nilai tukar) Terhadap IHSG}

Menurut Sukiorno (2016) Kurs atau nilai tukar adalah suatu nilai yang menunjukkan jumlah nilai mata uang dalam negeri yang diperlukan untuk mendapatkan satu unit mata uang asing. Kurs merupakan alat pengukuran yang digunakan untuk menilai harga mata uang domestik terhadap mata uang negara lain.Kurs mata uang asing menunjukkan harga atau nilai mata uang suatu negara dinyatakan dalam nilai mata uang negara lain. Kurs mata uang asing dapat juga didefinisikan sebagai jumlah uang domestik yang dibutuhkan, yaitu banyaknya Rupiah yang dibutuhkan untuk memperoleh satu unit mata uang asing.

Menurut Madura (2015) terdapat beberapa faktor yang dapat mempengaruhinya nilai tukar, antara lain: (1) laju inflasi relative, (2) suku bunga relative, (3) tingkat pendapatan relative, (4) kontrol pemerintah. Nilai tukar yang melonjak secara drastis tak terkendalikan akan menyebabkan kesulitan pada dunia usaha dalam merencanakan usahanya terutama bagi mereka yang mendatangkan bahan baku dari luar negeri atau menjual barangnya ke pasar ekspor. Saat ini, mata uang suatu negara bukan hanya sebagai alat pembayaran dalam perdagangan internasional, melainkan juga telah menjadi komoditi yang juga diperdagangkan sebagaimana layaknya barang pada umumnya. Oleh karena itu, pengelolaan nilai mata uang yang relatif stabil menjadi salah satu faktor moneter yang mendukung perekonomian secara makro. Pohan (2008).

Ketidak stabilan nilai tukar Rupiah terhadap Dollar dari waktu ke waktu menyebabkan ketidakstabilan harga saham. Kondisi ini cenderung menimbulkan keraguraguan bagi investor, sehingga kinerja bursa efek menjadi menurun. Hal ini dapat dilihat dari harga sekuritas atau harga saham yang sedang terjadi, baik indeks harga saham sektoral maupun Indeks harga saham gabungan, sehingga dikatakan nilai tukar berpengaruh positif terhadap Harga Saham Gabungan, Sukirno (2006), Pohan (2008), dan Madura (2015).

\section{Pengaruh Inflasi Terhadap IHSG}

Menurut Tandelilin (2010), inflasi adalah kecenderungan terjadinya peningkatan harga produk-produk secara keseluruhan sehingga terjadi penurunan daya beli uang. Sedangkan Sukirno (2006) menjelaskan bahwa inflasi merupakan suatu proses kenaikan harga-harga yang berbeda dalam sesuatu perekonomian. Inflasi terjadi ketika harga-harga 
terus merangkak naik sebagai akibat pertumbuhan ekonomi atau terlalu banyaknya uang yang beredar di pasaran.

Inflasi yang berlebih selalu berdampak buruk bagi perekonomian.), dampak inflasi dapat menimbulkan akibat buruk kepada individu, masyarakat dan kegiatan perekonomian secara keseluruhan, (Sukirno 2006). Inflasi berhubungan dengan suku bunga. Jika inflasi semakin tinggi tanpa diimbangi oleh kenaikan suku bunga maka keuntungan investasi terutama di pasar uang menjadi tidak menarik lagi.Sedangkan Diantoro (2010) menyebutkan dampak negatif dari inflasi adalah barang- barang menjadi langka di pasaran karena para konsumen cemas dengan kenaikan harga barang di keesokan harinya sehingga mereka terkena sindrom hoarding of goods (menimbun barang-barang/penimbunan) karena mereka lebih tenang menyimpan barang-barang kebutuhan daripada uang.Indikator Inflasi dapat menggunkan indeks harga konsumen, atau lebih dikenal dengan istilah Consumer Price Index(CPI) yaitu indeks harga dari barang-barang yang selalu digunakan para konsumen.(Sukirno 2006)

Pohan (2008) Inflasi yang tinggi dan tidak terkendali dapat menggganggu upaya bank dalam pengerahan dana masyarakat karena tingkat inflasi yang tinggi menyebabkan tingkat suku bunga riil menjadi menurun. Kenyataan demikian akan menghambat upaya perbankan dalam menghimpun dana masyarakat. Keadaan di mana kemampuan bank sangat rendah dalam menampung dana masyarakat akan mengurangi kemampuan perbankan untuk memberikan kredit. Dapat ditambahkan, laju inflasi yang tinggi (hyper inflation) akan menimbulkan ketidakpastian dalam berusaha sehingga mengganggu kegiatan operasional perbankan seperti pembuatan anggaran belanja dan perencanaan kredit yang akan mepengaruhi keadaan keuangan bank-bank. Sehingga dikatakan bahwa inflasi berpengaruh negative dan signifikan terhadap indeks harga saham gabungan, Manurung (2016) dan Tri Wisnu (2020).

\section{Pengaruh Suku Bunga Terhadap IHSG}

Suku bunga SBI adalah tingkat suku bunga yang ditentukan oleh Bank Indonesia atas penerbitan Sertifikat Bank Indonesia (SBI). Sertifikat Bank Indonesia (SBI) adalah surat berharga yang dikeluarkan oleh Bank Indonesia sebagai pengakuan utang berjangka waktu pendek (1-3 bulan) dengan sistem diskonto/bunga. Penetapan suku bunga (BI rate) oleh Bank Indonesia (BI) merupakan kebijakan moneter yang bertujuan untuk mengendalikan tingkat inflasi di Indonesia dan sekaligus memberikan sinyal kepada investor untuk melakukan investasi di pasar modal Indonesia.

Tingkat suku bunga merupakan jembatan penghubung antara pendapatan dan modal usaha. Tandelilin (2010) hubungan antara tingkat suku bunga dengan harga saham sebagai berikut : Perubahan suku bunga akan mempengaruhi harga saham secara terbalik, ceteris paribus. Artinya, jika suku bunga meningkat, maka harga saham akan turun dan sebaliknya. Jika suku bunga naik, maka return investasi yang terkait dengan suku bunga juga naik.

Fungsi suku bunga adalah sebagai daya tarik bagi para penabung yang mempunyai dana lebih, digunakan sebagai alat moneter dalam rangka mengendalikan penawaran dan permintaan uang yang beredar, sebagai alat kontrol bagi pemerintah terhadap dana langsung atau investasi pada sektor-sektor ekonomi, sebagai alat pemerintah untuk memanipulasi tingkat bunga.(Sunariyah, 2006).

Tandelilin (2010)Tingkat bunga yang tinggi akan menyebabkan return yang diisyaratkan investor dari suatu investasi akan meningkat. Investor cenderung untuk memilih investasi dengan harapan return yang didapatkannya lebih besar dan dengan risiko yang lebih kecil, maka dengan kenaikan tingkat suku bunga SBI akan menyebabkan investor berpindah berinvestasi dari pasar modal ke perbankan, sehingga dikatakan tingkat suku bunga berpengaruh signifikandan negatif terhadap IHSG. Putri, et al,. (2015) dan Tri Wisnu (2020). 


\section{Pengaruh pertumbuhan Ekonomi Terhadap IHSG}

Pertumbuhan eknomoi adalah sebuah proses pertumbuhan output perkapita jangka panjang yang terjadi apabila ada peningkatan output yang bersumber dari proses intern perekonomian itu sendiri dan sifatnya sementara. (Boediono 1999). Secara teori dapat dijelaskan bahwa pertumbuhan ekonomi adalah proses dimana terjadi kenaikan produk nasional bruto riil atau pendapatan nasional riil. Jadi, perekonomian dikatakan tumbuh atau berkembang bila terjadi pertumbuhan output riil. penelitian Yanuar (2011) yang membuktikan pertumbuhan investasi di suatu Negara akan dipengaruhi oleh pertumbuhan ekonomi di Negara tersebut. Semakin baik tingkat perekonomian suatu Negara, maka semakin baik pula tingkat kemakmuran peduduknya.

Tingkat kemakmuran yang lebih tinggi umumnya ditandai dengan adanya kenaikan tingkat pendapatan masyarakat. Dengan adanya peningkatan pendapatan tersebut, maka semakin banyak orang yang memiliki kelebihan dana, kelebihan dana tersebut dapat dimanfaatkan untuk disimpan dalam bentuk tabungan atau diinvestasikan dalam bentuk surat - surat berharga yang diperdagangkan dalam pasar modal seperti saham, maka dari itu semakin banyak orang yang menginvestasikan dananya dalam bentuk saham yang dikarenakan kenaikan pendapatan ekonomi sehingga indeks harga saham gabungan (IHSG) akan meningkat juga.

Salah satu tujuan utama pertumbuhan ekonomi adalah pengurangan tingkat kemiskinan, artinya pertumbuhan ekonomi seharusnya dapat mengurangi jumlah penduduk miskin secara signifikan. Salah satu penelitian yang menguatkan pendapat tersebut adalah penelitian yang dilakukan oleh Kakwani dan Pernia (2000) melaporkan hasil studinya dari penelitiannya di Filipina tentang "pertumbuhan ekonomi dan pengurangan kemiskinan". Dikatakan di dalam studinya bahwa peningkatan 1 persen output GDP akan mengurangi jumlah orang miskin di atas 1 persen. Sehingga dikatakan bahwa Pertumbuhan ekonomi berpengaruh positif terhadap indeks harga saham gabungan. Yunuar (2011) dan Kewal (2012).

\section{METODE PENELITIAN}

\section{Populasi dan Sampel}

Populasi dalam penelitian ini adalah semua periode perdagangan yang terdaftar di Bursa Efek Indonesia (BEI) sejak tahun 2017 sampai dengan 2020. Sampel yang akan digunakan untuk penelitian ini adalah periode pengamatan dari tahun 2017 sampai dengan 2020 dengan pertimbangan bahwa selama periode pengamatan, Bursa Efek Indonesia (BEI) telah mengalami market bearish dan market bullish karena dipengaruhi oleh berbagai makro ekonomi sehingga sangat sesuai dengan tujuan penelitian Metode pengumpulan data yang digunakan dalam penelitian ini adalah tehnik Dokumentasi melalui internet www.bi.go.id, www.bps.go.id penelusuran dokumen, atau publikasi informasi

\section{Operasionalisasi variabel}

Variabel dependent adalah Indeks harga saham Gabungan yaitu ukuran yang didasarkan dalam perhitungan statistiknya untuk mengetahui perubahan-perubahan harga saham setiap saat terhadap tahun dasar. Indeks harga saham gabungan menunjukkan pergerakan harga saham perusahaan yang tercatat di bursa efek secara umum sehingga keberadaan IHSG bisa dijadikan cerminan dari harga saham secara keseluruhan Indeks Harga Saham Gabungan (IHSG) dapat dihitung menggunakan sebagai berikut : (Halim, 2005).

$\mathrm{IHSG}_{t}=\frac{\mathrm{NP}_{t}}{\mathrm{ND}} \times 100 \%$

$I H S G_{t}=$ Indeks saham Gabungan pada hari berlaku

$\mathrm{NPt}=$ Nilai pasar pada hari berlaku 
$\mathrm{ND}=$ Nilai dasar

Variabel independent adalah sebagai berikut :

Nilai Kurs adalah suatu nilai yang menunjukan jumlah nilai mata uang dalam negeri yang diperlakukan untuk memperoleh satu unit mata uang asing. Untuk menentukan Nilai Kurs Rp/US\$ menggunakan data perubahan rata-rata nilai kurs tengah setiap bulan dengan satuan Rp/US\$ menggunakan rumus sebagai berikut:

$$
X t=\frac{K J+K B}{2} \text {...... }
$$

$\mathrm{Xt}=$ kurs tengah

$\mathrm{KJ}=$ kurs jual

$\mathrm{KB}=$ kurs beli

Inflasi secara umum adalah kenaikan harga-harga secara umum dan secara terus menerus. Untuk menentukan Inflasi dapat menggunakan data perubahan Indeks Harga Konsumen setiap bulan dengan satuan persentase (\%).

$$
\begin{aligned}
I F= & \frac{I H K t-I H K t-1}{I H K t-1} X 100 \% \ldots \ldots \ldots . . . . \\
I F & =\text { perubahan inflasi } \\
\mathrm{IHK}_{\mathrm{t}} & =\text { IHK periode sekarang } \\
\mathrm{IHK}_{\mathrm{t}-1} & =\text { IHK periode sebelumnya }
\end{aligned}
$$

Suku bunga BI adalah BI rate yang telah ditetapkan oleh Bank Indonesia dapat dijadikan sebagai suku bunga acuan oleh bank-bank yang ada di Indonesia dalam menentukan besarnya suku bunga simpanan dan pinjaman serta digunakan oleh Bank Indonesia sebagai sasaran suku bunga SBI yang diinginkan untuk pelelangan pada masa periode tertentu.

Suku Bunga $=\frac{\text { BI rate tahun-t }}{n}$

Bi rate tahun $=$ Tingkat suku bunga tahunan

$\mathrm{t} \quad=$ time

$\mathrm{n} \quad=$ banyaknya priode

Pertumbuhan ekonomi merupakan ukuran peningkatan nilai seluruh jasa dan barang jadi yang diproduksi oleh suatu negara selama kurun waktu tertentu PDB diukur dalam satuan rupiah berdasarkan harga konstan. Sementara ukuran pertumbuhan ekonomi sebagai berikut:

$$
\begin{aligned}
& R=\frac{\text { PDEt-PDBt-1 }}{\text { PDEt }-1} \text { X } 100 \% \text {......................................................................................................(5) } \\
& \mathrm{R} \quad=\text { Tingkat pertumbuhan ekonomi dalam satuan persentase }(\%) \\
& \mathrm{PDBt}=\text { Produk Domestik Bruto (pendapatan nasional riil) pada tahun berjalan. } \\
& \text { PDBt-1 }=\text { Produk Domestik Bruto (pendapatan nasional riil) pada tahun sebelumnya }
\end{aligned}
$$

\section{Teknik Analisis Data :}

Tehnik analisis data yang digunakan adalah regresi linear berganda dengan persamaan sebagai berikut: IHSG $=\mathbf{a}+\mathbf{b}_{1} I D R+\mathbf{b}_{2} I F+b_{3} S B I+b_{4} G D P+e$

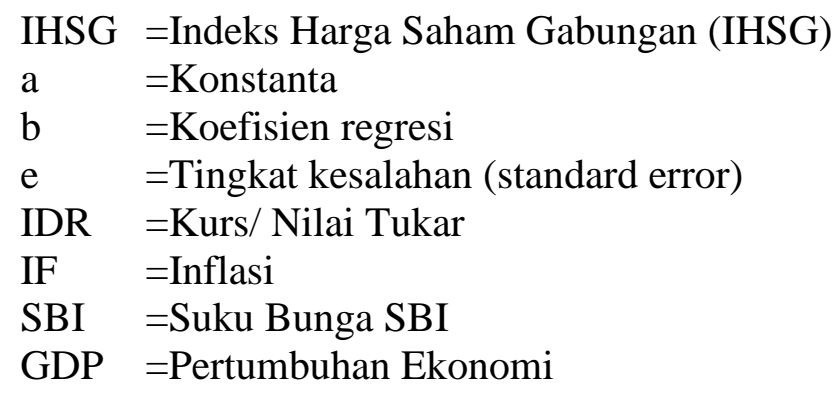




\section{HASIL PENELITIAN DAN PEMBAHASAN}

Sebelum pengujian hipotesis, dilakukan Uji Asumsi Klasik meliputi normalitas multikolinearitas, heteroskedastisitas, dan Autokorelasi. Dari hasil uji asumsi klasik variabel residual terdistribusi secara normal, nilai tolerance masing-masing variabel bebas memiliki nilai variance inflation factor (VIF) kurang dari 0,10 atau tidak ada satupun variabel bebas yang memiliki nilai VIF lebih dari 10, artinya tidak terdapat multikoloniaritas antar variable serta tidak terjadi heteroskedastisitas, serta tidak terdapat autokorelasi sehingga model regresi layak digunakan untuk memprediksi IHSG berdasarkan masukan keempat variabel independen (Kurs, Inflasi, Suku Bunga dan Pertumbuhan Ekonomi).Tehnik analisis data yang digunakan adalah regresi linear berganda dengan hasil penelitian ditunjukkan pada Tabel 1:

IHSG = 11.502,511 - 0,406 IDR - 461,949 IF + 203,375 SBI + 417,177 GDP + e Tabel 1 Hasil Analisis Regresi Berganda

\begin{tabular}{|c|c|c|c|c|}
\hline $\begin{array}{l}\text { Variabel } \\
\text { Independen } \quad \& \\
\text { Konstan }\end{array}$ & $\begin{array}{l}\text { Koefisien } \\
\text { regresi }\end{array}$ & $\begin{array}{l}\text { Standard of } \\
\text { Error }\end{array}$ & t. hitung & Signifinance \\
\hline Kurs & $-0,406$ & 0,091 & $-4,484$ & 0,000 \\
\hline Inflasi & $-461,949$ & 98,889 & $-4,671$ & 0,000 \\
\hline SBI & 203,375 & 79,289 & 2,565 & 0,014 \\
\hline GDP & 417,117 & 69,577 & 5,995 & 0,000 \\
\hline Kontan & $11.502,511$ & 1309,847 & 8,782 & 0,000 \\
\hline R Square & 0,854 & & & \\
\hline Adjusted R Square & 0,729 & & & \\
\hline F. Hitung & 28,942 & & & \\
\hline Signifinance &, $000^{\mathrm{a}}$ & & & \\
\hline
\end{tabular}

Dari hasil persamaan tersebut di atas, dapat dijelaskan sebagai berikut:

1. Kurs (IDR) mempunyai pengaruh negatif terhadap pergerakan indeks harga saham gabungan. Besarnya nilai koefisien regresi sebesar-0,406 artinya apabila kurs naik sebesar 1\% maka indeks harga saham gabungan akan turun sebesar 0,406 dan apabila kurs turun sebesar 1\% maka indeks harga saham gabungan akan naik sebesar 0,406.

2. Inflasi (IF) mempunyai pengaruh negatif terhadap indeks harga saham gabungan.. Besarnya nilai koefisien regresi sebesar $-461,949$ artinya apabila Inflasi naik sebesar $1 \%$ maka indeks harga saham gabungan akan turun sebesar 461,949 dan apabila Inflasi turun $1 \%$ maka indeks harga saham gabungan akan naik sebesar 461,949.

3. Suku Bunga BI(SBI) mempunyai pengaruh positif terhadap indeks harga saham gabungan. Besarnya nilai koefisien regresi Suku Bunga BI (SBI) sebesar 203,375 artinya bahwa apabila SBI naik sebesar 1\% maka indeks harga saham gabungan akan naik sebesar 203,375 dan apabila SBI turun sebesar 1\% maka indeks harga saham gabungan akan turun sebesar 203,375.

4. Pertumbuhan Ekonomi (GDP) mempunyai pengaruh positif terhadap indeks harga saham gabungan. Besarnya nilai koefisien regresi pertumbuhan ekonomi (GDP) sebesar 417,117 artinya bahwa apabila GDP naik sebesar 1\% maka indeks harga saham gabungan akan naik sebesar 417,117 dan apabila GDP turun sebesar 1\% maka indeks harga saham gabungan akan turun sebesar 417,117.

5. Nilai koefisien korelasi mengukur kereratan hubungan antara kurs, inflasi, suku bunga BI dan pertumbuhan ekonomi dengan indeks harga saham gabungan.Nilai koefisien korelasi sebesar 85,4\%. Dari nilai koefisien korelasi tersebut dapat disimpulkan kurs, inflasi, suku 
bunga BI dan pertumbuhan ekonomi mempunyai hubungan yang positif dan kuat dengan indeks harga saham gabungan

6. Nilai koefisien determinasi mengukur variasi indeks harga saham gabungan dapat dijelaskan variasi kurs, inflasi, suku bunga BI dan pertumbuhan ekonomi. Nilai koefisien determinasi adalah $72,9 \%$ artinya bahwa Indeks harga saham gabungan dapat dijelaskan oleh variasi kurs, inflasi, suku bunga BI dan pertumbuhan ekonomi sebesar $72,9 \%$ dan selebihnya sebesar $27,1 \%$ dapat dijelaskan olek faktor lain yang tidak terliput dalam model penelitian ini seperti variabel faktor fundamental perusahaan.

\section{Pengujian Hipotesis}

Pengujian hipotesis yang dilakukan adalah pengujian secara parsial (uji t) dan pengujian secara simultan (uji F). Berdasarkan uji t yang ditunjukkan pada Tabel 1. di atas dapat dijelaskan bahwa kurs berpengaruh negative dan signifikan terhadap indeks harga saham gabungan, hal ini ditunjukkan dari nilai signifikan $<0,05$, Nilai $\mathrm{t}_{\text {hitung }}$ Kurs $<$ nilai $\mathrm{t}_{\text {tabel }}$ $(-4,484<-2,017)$ maka H1 diterima. Sehingga dapat disimpulkan bahwa Kurs mempunyai pengaruh yang signifikan terhadap indeks harga saham gabungan di Bursa Efek Indonesia (BEI)

Inflasi berpengaruh negative dan sinifikan terhadap indeks harga saham gabungan, hal ini ditunjukkan dari nilai signifikan $<0,05$. Nilai $t_{\text {hitung }}$ Inflasi $<$ nilai $t_{\text {tabel }}(-4,671<-$ 2,017) maka H1 diterima. Sehingga dapat disimpulkan bahwa variabel Inflasi mempunyai pengaruh negatif dan signifikan terhadap indeks harga saham gabungan di Bursa Efek Indonesia (BEI)

Suku bunga berpengaruh positif terhadap indeks harga saham gabungan hal ini ditunjukkan dari nilai signifikan $<0,05$. Nilai $t_{\text {hitung }} \mathrm{SBI}>$ nilai $\mathrm{t}_{\text {tabel }}(2,565>2,017)$ maka H1 diterima. Sehingga dapat disimpulkan bahwa variabel Suku bunga BI mempunyai pengaruh yang signifikan terhadap indeks harga saham gabungan di Bursa Efek Indonesia (BEI)

Pertumbuhan ekonomi berpengaruh positif dan signifikan terhadap indeks harga sahan gabungan, hal ini ditunjukkan dari nilai signifikan $<0,05$. Nilai $t_{\text {hitung }}>$ nilai $t_{\text {tabel }}(5,995>$ 2,017) maka H1 diterima. Sehingga dapat disimpulkan bahwa variabel Pertumbuhan ekonomi mempunyai pengaruh yang signifikan terhadap indeks harga saham gabungan di Bursa Efek Indonesia (BEI)

Pengujian secara simultan: Kurs, Inflasi, Suku bunga BI dan Pertumbuhan Ekonomi berpengaruh secara simultan dan signifikan terhadap indeks harga saham gabungan hal ini ditunjukkan dari nilai signifikan $<0,05$. Nilai $F$ hitung $>F$ tabel $((28,942>2,58)$ maka H1 diterima. Sehingga dapat disimpulkan Kurs, Inflasi, Suku bunga BI dan Pertumbuhan Ekonomi berpengaruh secara simultan dan signifikan terhadap indeks harga saham gabungan di Bursa Efek Indonesia (BEI).

\section{PEMBAHASAN}

Berdasarkan hasil perhitungan yang ditunjukkan Tabel 1. menunjukkan nilai koefisien regresi kurs -0.406, artinya bahwa Kurs (IDR) berpengaruh Negatif terhadap indeks harga saham gabungan. Apabila Kurs naik sebesar 1\% maka indeks harga saham gabungan akan turun sebesar 0,406 sebaliknya, jika Kurs turun sebesar 1\% maka indeks harga saham gabungan akan naik sebesar 0,406 , hal ini di tunjukkan dari nilai arah koefisien regresi. Nilai $\mathbf{t}_{\text {hitung }}$ Kurs $<$ nilai $\mathrm{t}_{\text {tabel }}(-4,484<-2,017)$ dengan signifikan sebesar 0,000 $<0,05$ maka H1 diterima. Sehingga dapat disimpulkan bahwa variabel Kurs mempunyai pengaruh yang signifikan terhadap indeks harga saham gabungan di Bursa Efek Indonesia. Nilai signifikan ini menunjukkan bahwa peningkatan nilai Kurs memiliki pengaruh namun arahnya negatif terhadap pergerakan indeks harga saham gabungan di bursa efek Indonesia.

Dalam hal ini fluktuasi nilai tukar rupiah terhadap mata uang asing akan sangat 
mempengaruhi iklim investasi di dalam negeri khususnya di pasar modal. Perusahaanperusahaan di Indonesia yang sudah go public dengan masih mengandalkan bahan baku impor dari luar negeri akan menerima dampak negatif apabila mata uang rupiah terdepresiasi atau mengalami pelemahan terhadap mata uang dollar AS. Hal ini akan mengakibatkan naiknya bahan baku tersebut. Kenaikan biaya produksi akan mengurangi tingkat keuntungan perusahaan akan mendorong investor untuk melakukan aksi jual terhadap saham-saham yang dimilikinya. Apabila banyak investor yang melakukan hal tersebut, tentu akan mendorong penurunan indeks harga saham gabungan. Hasil penelitian ini didukung oleh Yusnita Jayanti (2012) dan Tri Moch Arifin (2014) yang menyatakan Kurs (IDR) berpengaruh negatif secara parsial dan signifikan terhadap indeks harga saham gabungan.

Inflasi (IF) berpengaruh negatif terhadap Indeks harga saham gabungan. Nilai koefisien regresi sebesar $-461,949$ artinya apabila inflasi naik sebesar $1 \%$ maka harga saham gabungan turun sebesar 461,949 begitu juga sebaliknya, jika inflasi turun $1 \%$ maka indeks harga saham gabungan akan naik sebesar 461,949, hal ini di tunjukkan dari nilai arah koefisien regresi. Nilai thitung Inflasi $<$ nilai tabel $(-4,671<-2,017)$ dengan signifikan sebesar $0,000<0,05$ maka H1 diterima. Sehingga dapat disimpulkan bahwa inflasi berpengaruh negative dan signifikan terhadap indeks harga sahan gabungan di Bursa Efek Indonesia (BEI). Hal ini didukung Thobarry (2009). Salah satu faktor penting yang dipertimbangkan para investor sebelum berinvestsi di suatu saham perusahaan adalah inflasi, karena apabila laju inflasi tidak dikendalikan akan memberikan dampak bagi negara. Inflasi tinggi tentunya mempengaruhi kemampuan beli masyarakat dan menghambat penjualan yang kemudian mempengaruhi keuntungan perusahaan. Profitabilitas perusahaan yang melemah menyebabkan penanam modal mengambil kembali sahamnya untuk kemudian mencari investasi yang lebih menguntungkan dan berakibat pada melemahnya harga saham. Akibat menurunnya harga saham, indeks harga saham gabungan juga turun.

Suku bunga BI (SBI) berpengaruh positif dan signifikan terhadap indeks harga saham gabungan, nilai koefisien regresi sebesar 203,375 artinya bahwa apabila suku bunga (BI) naik $1 \%$ maka indeks harga saham gabungan naik sebesar 203,375 begitu juga sebaliknya hal ini ditunjukkan dari nilai arah koefisien regresi. Nilai $t_{\text {hitung }} \mathrm{SBI}>$ nilai $\mathrm{t}_{\text {tabel }}(2,565>2,017)$ dengan signifikan sebesar 0,014 $<0,05$ maka H1 diterima. Sehingga dapat disimpulkan bahwa Suku bunga BI mempunyai pengaruh yang signifikan terhadap indeks harga saham gabungan di Bursa Efek Indonesia (BEI). Penelitian ini didukung hasil penelitian Indra Maimuna (2017). Hal ini dapat dijelaskan bahwa saat suku bunga BI naik akan mempengaruhi suku bunga deposito dan juga suku bunga kredit dimasyarakat, Ketika Saham di sektor perbankan meningkat maka IHSG juga ikut meningkat karena saham di sektor perbankan merupakan salah satu sektor yang berperan besar dalam peningkatan IHSG. Semakin tinggi suku bunga yang ditawarkan, semakin tinggi pula keinginan masyarakat untuk berinvestasi dalam pasar uang.

Pertumbuhan ekonomi (GDP) berpengaruh positif dan signifikan terhadap indeks harga sahan gabungan, nilai koefisien regressi sebesar 417,177 artinya apabila pertumbuhan ekonomi naik sebesar 1\% maka indeks harga saham gabungan naik sebesar 417,117, begitu juga sebaliknya. Hal ini ditunjukkan dari nilai arah koefisien regresi. Nilai $t_{\text {hitung }}$ GDP $>$ nilai $\mathrm{t}_{\text {tabel }}(5,995>2,017)$ dengan signifikan sebesar $0,000<0,05$, maka H1 diterima. Sehingga dapat disimpulkan bahwa Pertumbuhan ekonomi mempunyai pengaruh yang signifikan terhadap indeks harga saham gabungan di Bursa Efek Indonesia (BEI). Hal ini didukung Febriyanto (2016), Kusuma \& Badjra (2016).

Peningkatan Pertumbuhan Ekonomi (GDP) suatu negara akan mempengaruhi oleh pertumbuhan investasi di Negara tersebut. Hal ini dapat dijelaskan bahwa pada saat indeks harga saham gabungan dipengaruhi oleh pertumbuhan ekonomi maka tingkat perekonomian suatu Negara akan semakin baik. Tingkat kemakmuran yang lebih tinggi umumnya ditandai 
dengan adanya kenaikan tingkat pendapatan masyarakat.

Dengan adanya peningkatan pendapatan tersebut, maka semakin banyak orang yang memiliki kelebihan dana, kelebihan dana tersebut dapat dimanfaatkan untuk disimpan dalam bentuk tabungan atau diinvestasikan dalam bentuk surat- surat berharga yang diperdagangkan dalam pasar modal seperti saham, maka dari itu semakin banyak orang yang meniginvestasikan dananya dalam bentuk saham yang dikarenakan kenaikan pendapatan ekonomi maka indeks harga saham gabungan juga akan meningkat.

Dilihat dari uji F pada pada table 1 menunjukkan Kurs, Inflasi, Suku bunga BI dan pertumbuhan Ekonomi memiliki pengaruh secara simultan dan signifikan terhadap indeks Harga Saham gabungan di Bursa Efek Indonesia. Nilai signifikan sebesar 0,000 lebih kecil dari tingkat signifikansi 0,05 dan diperoleh $F_{\text {hitung }}$ sebesar 28,942 dan $F_{\text {tabel }}$ sebesar 2,58 $(28,942>2,58)$ maka $\mathrm{H}_{1}$ diterima. Sehingga dapat disimpulkan bahwa Kurs, Inflasi, Suku bunga BI dan pertumbuhan Ekonomi berpengaruh secara simultan dan signifikan terhadap indeks Harga Saham gabungan.

Nilai koefisien korelasi sebesar $85,4 \%$ artinya bahwa terdapat korelasi positif dan kuat antara Kurs, Inflasi, Suku bunga BI dan pertumbuhan Ekonomi dengan indeks harga saham gabungan. Nilai koefisien determinasi yang ditunjukkan bahwa nilai R-square sebesar 72,9\% artinya variasi Kurs, Inflasi, Suku bunga BI dan pertumbuhan Ekonomi mampu menjelaskan variasi indeks harga saham gabungan sebesar $72,9 \%$. Sedangkan sisanya sebesar $27,1 \%$ dapat dijelaskan oleh variabel lain yang tidak terlibat dalam penelitian ini.

\section{KESIMPULAN}

1. Kurs, Inflasi berpengaruh negative dan signifikan terhadap indeks harga sahan gabungan di Bursa efek Indonesia (BEI); Suku bunga BI, Pertumbuhan ekonomi berpengaruh positif dan signifikan terhadap indeks harga sahan gabungan di Bursa efek Indonesia (BEI).

2. Kurs, Inflasi, Suku Bunga BI dan Pertumbuhan ekonomi berpengaruh simultan dan signifikan terhadap Indeks harga saham gabungan di bursa efek Indonesia (BEI).

Dengan melihat hasil penelitian bahwa Kurs, inflasi, Suku Bunga BI dan Pertumbuhan Ekonomi perlu dipertimbangkan untuk mengestimasi Indeks harga saham gabungan (IHSG) di Bursa Efek Indonesia. Bagi investor atau calon investor yang ingin melakukan investasi di pasar modal sebaiknya mempertimbangkan faktor makroekonomi meliputi: Kurs, inflasi, Suku Bunga BI dan Pertumbuhan Ekonomi dalam pengambilan keputusan invesatasi, karena secara simultan keempat variabel mempunyai pengaruh yang signifikan terhadap Pergerakan Indeks Harga Saham Gabungan (IHSG) di Bursa Efek indonesia periode 2017-2020.

\section{DAFTAR PUSTAKA}

Anoraga, Pandji dan Piji Pakarti. 2008. Pengantar Pasar Modal. Semarang: Rineka Cipta.

Arifin, Tri Moch. 2014. Pengaruh Inflasi, Suku Bunga Sbi, Perubahan Kurs, Dan Standard \& Poor's 500 Terhadap Indeks Harga Saham Gabungan (IHSG). Jurnal Manajemen Keuangan Vol 1 No 3 diakses tanggal 01 Mei 2021

Boediono.1999 Teori Pertumbuhan Ekonomi. BPFE UGM, Yogyakarta.

Brigham \& Houston. 2014. Essentials of FinancialManagement. Dasar-dasar Manajemen

Keuangan.Terjemahan Ali Akbar Yulianto. Buku 2. Edisi 11.Jakarta: Salemba Empat Diantoro, Yimi S.T. 2010. Emas, Investasi \& Pengolahannya. Jakarta: PT Gramedia

Fahmi, Irham. 2015. Manajemen Investasi: Teori dan Soal Jawab. Edisi 2. Jakarta: Salemba Empat. 
Febriyanto, S.A. 2016. Pengaruh Nilai Tukar Rupiah, Suku Bunga, Inflasi dan Produk Domestik Bruto terhadap Indeks Harga Saham Gabungan di Bursa Efek Indonesia. Jurnal Ilmiah Mahasiswa FEB, 2(4):1-18.

Ghozali, Imam. 2018. Aplikasi AnalisisMultivarians dengan Program SPSS.Semarang : Badan PenerbitUniversitas Diponegoro.

Handiani. 2014. Pengaruh Harga Emas Dunia, Harga Minyak Dunia dan Nilai Tukar Dolar Amerika/Rupiah Terhadap Indeks Harga Saham Gabungan Pada Periode 2008-2013. E-Journal Graduate Unpar Vol. 1, No. 1.

Husnan, suad 2009. Teori Portofolio \& Analisis Sekuritas (Edisi ke-4). UPP STIM YKPN, Yogyakarta, Indonesia.

Halim, Abdul. 2005. Analisis Investasi (Edisi ke-2). Salemba Empat, Jakarta, Indonesia

Indra. 2017. Pengaruh tingkat inflasi, Nilai tukar rupiah dan Suku Bunga sertifikat Bank Indonesia terhadap Indeks Harga Saham Gabungan di bursa efek Indonesia http://eprints.perbanas.ac.id, diakses tanggal 24 Februari 2021

Jogiyanto. 2017. Teori Portofolio dan Analisis Investasi, Edisi Kesebelas. Yogyakarta: BPFE.

Kakwani, N., \& Pernia, E. M. 2000. What is Pro-poor Growth?. Asian Development Bank, 18 (1), 1-16.

Kewal, 2012. Pengaruh Inflasi, Suku Bunga, Kurs, dan Pertumbuhan PDB terhadap Indeks Harga Saham Gabungan.. http://journal.uny.ac.id/Diakses tanggal 24 Februari 2021

Kumalasari et. Al 2016. Pengaruh Nilai Tukar, Bi Rate, Tingkat Inflasi, dan Pertumbuhan Ekonomi Terhadap Indeks Harga Saham. Jurnal Administrasi Bisnis (JAB), 34(1), 130-137.

Kusuma, E. M.P., Badjra, B.I. 2016. Pengaruh Inflasi, Jub, Nilai Kurs Dollar,dan Pertumbuhan Gdp terhadap IHSG di Bursa Efek Indonesia. E-Jurnal Manajemen Unud, 5(3):1829-1858.

Madura, Jeff. 2015. International Financial Management. Jakarta: Erlangga

Manurung, R. (2016). Pengaruh Inflasi, Suku Bunga dan Kurs terhadap Indeks Harga Saham Gabungan pada Bursa Efek Indonesia. Jurnal Ekonomi, 19(4), 148-156

Pohan. Aulia. 2008. Kerangka Kebijakan Moneter dan Implikasinya di Indonesia. RajaGrafindo Persada. Jakarta.

Putri, K. T. R., Darmawan, N. A. S., \& Sulindawati, N. L. G. E. 2015. Pengaruh Tingkat Suku Bunga SBI, Kurs Mata Uang Rupiah Atas Dollar As, dan Indeks Dow Jones Terhadap Indeks Harga Saham Gabungan (IHSG) Pada Bursa Efek Indonesia (BEI). EJournal S1 Universitas Pendidikan Ganesha, 3(1).

Raharjo, Sugeng. 2012. Pengaruh Inflasi, Nilai Kurs Rupiah, dan Tingkat Suku Bunga Terhadap Harga Saham di Bursa Efek Indonesia. e-journal.stieaub.ac.id/index.php/probank/ diakses tanggal 29 Maret 2021

Rivai, Veithzal dan Andi Buchari. 2009. Islamic Economics Ekonomi SyariahBukan Opsi, Tetapi Solusi, Jakarta: Bumi Aksara.

Sekaran, Uma. 2009. Metodologi Penelitian Untuk Bisnis, Salemba Empat: Jakarta. Buku 2

Situmorang, SH 2008 Filsafat Ilmu dan Metode Riset, USU Press, Medan

Sukirno, Sadono. 2006, Pengantar Teori Makro Ekonomi, Edisi ke-2, PT. Raja Grafindo Persada, Jakarta.

Sunariyah. 2006 Pengantar Pengetahuan Pasar Modal. Edisi Kelima. UPP STIM YKPN. Yogyakarta.

Tandelilin,. 2010. Portofolio dan Investasi Teori dan Aplikasi. Yogyakarta: Kanisius.

Thobarry, Achmad Ath. 2009. Analisis Pengaruh Nilai Tukar, Suku Bunga, Laju Inflasi Dan Pertumbuhan GDP Terhadap Indeks Harga Saham Sektor Properti. Tesis Universitas Diponegoro. Semarang

Tri Wisnu. 2020. Analisis Pengaruh Inflasi, Nilai Tukar Rupiah, BI Rate, Jumlah Uang 
Beredar, dan Indeks Shanghai Stock Exchange terhadap Indeks Sri Kehati di Bursa Efek Indonesia periode 2014-2019. Jurnal ilmu manajemen volume 8 nomor 4

Wibowo et. Al 2016. Analisis Pengaruh Tingkat Inflasi, Suku Bunga BI, Nilai Tukar US Dollar Pada Rupiah, Jumlah Uang Beredar, Indeks Dow Jones, Indeks Nikkei 225, dan Indeks Hangseng Terhadap Pergerakan Indeks Harga Saham Gabungan (IHSG) periode tahun 2010-2014. Journal Of Accounting, Volume 2 No.2.

Yanuar et. Al. 2011. Pengaruh Kinerja Keuangan Terhadap Alokasi Belanja Modal dan Pertumbuhan Ekonomi Kabupaten/Kota di Jawa Tengah. Jurnal Media Riset Akuntansi. Vol. 1 No.2. Halaman 109 - 124.

Yusnita 2012. Pengaruh Tingkat Inflasi, Tingkat Suku Bunga BI, Nilai Tukar Rupiah, Indeks Dow Jones, dan Indeks KLSE terhadap Indeks Harga Saham Gabungan (IHSG). Jurnal Ilmu Administrasi Vol 1 No 4 diakses pada 01 mei 2021 